\title{
[パネルディスカッション I]
}

\author{
頸 部 外傷 (喉 頭 気管外傷) \\ 司会 広戸幾一郎（九 大) - 黒住静之 (広 大) ・佐 藤 武 男 (熊 大) \\ 広 瀬 信 大) ・武本欣也 (北里大) - 小宮山荘太郎（旭川大）
}

\section{I. 新鲜例について}

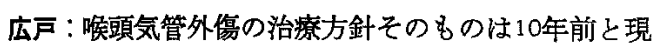
在と少しも変っていません，ただ経駼例が少いために， 具体的治㙩法に自信がないといらのが現状であららと思

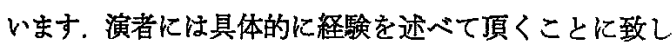
ます，最初に喉頭外傷の新鮮例飞ついて討議しますが， この浩湶汇あたっては，1）気道礁保が最優先するが， なるへく低位で気管切開を行って喉頭哆開部化括入され ているカニューレは拔去する，2）喉頭気管会道瘼を閉 鋇する．3）皮庯，軟骨注細断されていても可及的保存 する，4）ステロイド，抗生物質を使用して瘦痘化を防 〈゙，5）内腔の壊死組織が脱落したら早期に core mold を搏入する，以上が新鮮例化対する基本的沿滰方針であ ります。をれでは擷いします。

佐藤：新鮮外稘の多くは救急外来を受䛦するので，理 想としては救急外科医とチームを組む必要があり，これ により陳旧例にみられるよらな種々の合併症を防止する ことができる。

\section{1）䫫部外智の重症度診断}

一般に新部外傷の重症度注極めて高いことが多いの でまず重症度の判定が重 要である。(1)外傷範囲の確 認.これには頭部および腹部外傷の合併の有無を確詡せ ね洼ならない，(2)外傷機転が単なる打撲傷かまたは重症 度の高、鈍的外賃かを知らなければならない．鈍的外傷 と注頉部方全く無防備の状況下において起る，例えば車 から振り落されたとか, 単車事故, 壁落外賃の場合に多 い. (8)意識障害を合併している場合は最も重症である。 (4)心血管系障害, 呼吸困難の程度を知らねばならない。 要するに意識障害がみられ，鈍的外傷であり，呼吸困難 がある場合は極めて重症と診断する。この場合直ちに気 道確保が必要であり，緊急的には高位気管切開を行ら。 しかし後に低位にやり直す。

2）㖣部外倁の病態診断

問診（音質，咳，血痰，喀血，嘔吐，與下障害等）を 行以，触診にて皮下出血，気腫の筑囲，喉頭軟骨骨折，
気管外傷の有無を知り, 内視鏡検查にて粘膜下出血, 浮 腫の程度, 声帯運動障害, 食道損傷の有無を確診し, さ らにレントゲン検查を行ら.

3) 気道確保後の処置

気道確保後, 全身所見が安定してから, 外傷程度, 狭 窄部位などを確認するまず低位気管切開にやり直す。 次に外傷の程度に応して，骨折の整復，粘膜の縫合など を慎重に行々，時に core mold を㧴入し, diaphragma, webを残さない再建術を行う，輪状軟骨板の骨折，気管 膜部の損傷により，食道・喉頭瘦，食道・気管㾇がある 場合には特に縫合に意を用う。さらに抗生物質を強力に 投与し，反回神経麻軒を防止するため場合によりステロ イドを内服させている，人工呼吸の必要がある場合，と くに小児・女性では気管切開口より挿管（ダプルカフ 付）を行った方がよい 複雑な骨折では整復後に喉頭内 腔を前方に開放して 2 次的に形成を行うこともある。

また簡単な切創であって，呼吸困難がない場合でも， 後に狭窄をきたす例があるので，充分に病態を確認して web を残さないように処置すべきである.

4) 死亡例の検討

喉頭の非開放性の銛的外傷患者に対して，気管切開の 時期決定は意外にむつかしいことが多い，その時期を失 して死亡した症例を供覽する。この症例は泥酔・けんか ・意識喪失の状況下での倠頭の鈍的外傷であり，17時間 後, 救急外来を受診した. 喉頭内腔右壁に粘膜下出血, 浮腫がみられたが，声带運動は良好であったので入院の 上経過をみることになった，ところが次第に呼吸困難が 増覀し, 入院後 4 時間後の気管切開手術中に意識咞失し た.さらに人工呼吸を 5 日間続けたが死亡した。

本例には法医解剖が行われた，喉頭所見は喉頭内腔右 壁に著明な粘膜下出血, 高度の浮腫所見がみられ, 組織 学的所見では右仮声帯, 声帯の粘膜下, 筋層内に顕著な 出血病変が確認された．ほぼ上喉頭動脈の領域に一致し た出血であった。

本例のごとく泥酔，意識障害，無防備の状況下の鈍的 
外稘では重篤な経過をたどることが多いのである，した がって気道確保は可能な限り早期に行うべきである。 た鈍的外傷患者は入院の上最短 48 時閒の経過㓋察が必要 であり，初診時に気道症候（呼吸困難など）がなくても 気道確保をしておいた方がよいと思う。

結論として，救急時に充分に処置すれば，陳旧例にみ られる狭窄病変は防止できると思 5 .

黒住：新鮮例についての経験は少なく，多くを語る材 料を持っていないが，陳旧例の経騟からして，新鮮例の 処置について次のことを望みたい．

1. 新鮮例の適切な処置は慢性狭窄防止極为て重要で ある.

2. 喉頭切創よりのカニューレ挿入, coniotomy 巣 急の場合には止むを得ないが，危急の事態は脱したなら ば適正な気管切開にあらためるべきである。

3. 軟骨, 粘膜は極力, 温存利用すべく, ぶらぶらに なっている場合でむ縫合ないし圧抵し，切除しない

4. 以上のよらなことがらは咽喉科医としては初歩的 なことであるが，新鮮例が運び込まれるのを常とする救 急外科，一般外科ではそれらが屡々守られていないため に，慢性狭窄をきたす事例が少なくない，したがって， 救急外来一の参加, 到部外傷を含む救急処圆の卒前卒後 教育にわれわれはより積極的でなければならない．

広瀬：まず気道の確保が最重要で, 気管切開の必要が あれば可及的下位に行い，もし上位気切が行われていれ ば下位にあけな括す 止血，損傷状況の精查に続いて， 内膑, 軟部組織の復元, 維合をできるだけ正確に行ら. もし内腔粘膜の欠塤が大きければ, 粘膜の遊離移植を通 常口腔粘脱より行う. 次いで甲状㳄骨, 輪状軟骨, 気管 輪など外枠の整復, 固定を行う。通常ステンレススチー ルワイヤーで継合している.コアー・モールドの捙置は 内腔確保のために不可欠で，予め用意したシリコン製， レジン製などのものを用いるか，または手術用手袋の指 の中にシリコン・スポンデなどを固くつめて㧴入するこ とで目的を達することができるが, 後者が簡便で優れて いると思う。モールドが苝下運動によりずれるのを極力 少くするために，皮覻面より系を通してモールドを固定 する，形部皮膚は丁寧に縫合し，もし久損が大きけれ ば，局所皮弁で補ら。

武本：症例は 21 才の男子で急性喉頭蓋炏による呼吸困 難のため某病院で緊急気管切開が行かれた. 術後の管理 のため当院へ檕院してきた. 来院時診察にて高位気管切 開術が行われていると判断し，ただちに第II第IV気管
輸の䦎に新しい気管切開孔を設置し，既切開孔を精查す るために喉頭截開術を行った，その所見は右甲状軟骨板 の下端が幅 $10 \mathrm{~mm}$, 高さ $5 \mathrm{~mm}$ にわたって切除され，輪 状甲状鞄帯も切断されていた. この損傷部より金属カニ ニーレは声門下腔粘膜をつき破って挿入されていた，損 傷を受けた皮膚，勒帯および声門下腔の粘膜を修復し， 開放創とした。 2 週間後, 声門下腔粘膜面に肉芽が発生 していないことを確認して癗孔を閉鎖しカニューレを抜 去した. 最近気管切開の適应症が拡大され，気管切開を 行ら機会が多くなっている. 次の症例は这出血による呼 吸管理のため気管切開が行われたが, 剖検により辅状甲 状䩓帯に気管切開孔が設置されていたことが判明した。

このように救命処置として高位気管切開により気道が 確保された後は，原疾患の治療に注意が向けられ，社会 復帰の時期になって気道狭窄といら後遺症に苦しむこと になりがちである．したがって高位気管切開が行われた 場合は，躊躇することなく，第 II～第IV気管輪の間に再 気管切開を施行し，既切開孔を修復することが最善と思 われる。

小宮山：私の経験した喉頭気管外傷の新鮮例は 1 例で ある. 受傷約 4 時間後に手術を行った。

症例は38才男. 職業は漁師. 現病歴：1日の仕事を終 え, 仲間と酒を飲んでいるらち口論となり, 漁師包丁で 側頸部を切りつ沙られた。 その直後より呼吸困難・出 血・血痰・失声等の症状を呈し, 直ちに救急病院に入院 した.

約 4 時間後私どもが診察したとき, 症例は受傷した創 の間を通り, 前後に切離された甲状軟骨から気管内チュ 一ブが挿入されていた.切創は耳下腺直上の皮膚をそぎ, 莖動脈分岐部に至り，上甲状腺動脈を管出し甲状靯骨と 輪状軟骨を側面より切断していた，輪状軟骨部の稘は食 道に達し，また同側の半回神経を切断していた。

止血後・下気管切開を行い，充分な視野を得る目的で 横切開を加え甲状軟骨, 輸状軟骨・気管を露出した. 切 創の方向および哚さを充分に確認したのち，カットグー 卜を用い，食道・気管・喉頭の順に形成・縫合を行っ た.

この症例の経過は非常によく, 術後 8 日目に㸴腔より の栄盖チニーブを抜去, 術後 3 週閒で気切孔を閉鎖し退 院した，退院後も喉頭・気管内腔に肉芽をつくることな く，漁師として働いている．ただ患側の反回神経麻連仗 今日な打続いているが，患者が治潦を希望しないので放 置している. 
広戸：では討䄖に移ります，喉頭気管外倁の新解例に 奶して，診断のためどのような検査を行っていますか。

佐藤：到部触診で皮下気腯の有無および程度をみま †. 発声洔と呼吸時について, 正面と側面の娭顽高圧 (断層) X線撮影をする。間接喉頭鏡検查を行ら。これ で内腔が視えない場合には直達鏡検查を行います。

広戸 : 呢頭外傷直後の気管切開は緊急のため輸状甲状 膜あるいは輪状軟骨位になされることが多いが，落ち着 いて気管切開できるための良い方法はありませんか。

黑住：輸血針を $4 ， 5$ 本輪状甲状膜あるいは気管壁を 通して制入すれば，呼吸困難は軽減します。

広戸：私はモーターバイクで横断中，遮断機で前頸部 を打撲した患者で，皮虐に損傷なく，诶頭鏡像む正常， ただ皮下気腫が颈められるだけで気管が完全に断裂され ていた例を経験している．㬋頭外傷直後は病変は軽度で 後病変が悪化する場合があるといらが，外傷後何日間 位観察をつぶけるべきでしょうか.

佐藤：最低48時間観察すべきと思う。この期間には呼 吸困難に注意します。

広戸 : core mold について具体的に説明して下さい

広瀨：レジン, シリコン製，ビニールチューブなど予 め各種のサイズ，形驡のものを用意しておけばよいが， 实際にはむずかしい，最近手微用ゴム手袋の指の部分に スポンヂ様のものを巻いてつめて用いているが，巻き方 により, 種くの硬さのむのが得られ，簡便で実用性が高 いと思います。

広戸：術後処置としての抗生物澌，ステロイドの投与 について御発言ありませんか.

小宮山：術創を生食水でよく洗浄したのちは，㖫頭部 切の術後に準じて行う。ステロイドは使用方法が難しい ので, 私敨投与していません。

広戸：他に何か追加すべきことはありませんか．

武本：症例は 1 カ月前に自動車事故にてハンドルで前 频部を打撲したが，外観上，何ら異常所見が孙った。

受傷約 1 力月後より，急に呼吸困難とチアノーゼをきた すようになった。気管切開後に喉頭造影を行った，その 所見は声門の高さにて前連合部より後連合部にかけて境 界鮮明な陰影欠損がみられ，後連合部にかららじて造影 刘が通過していた：このように打撲だけでも，喉頭腔に 肉芽內隔膜が発生することがあるので, 経過, 観察が必 要と思われた。

II. 陳旧例について

広戸：侯頭気管外傷の陳旧例の討議に入りますが，陳

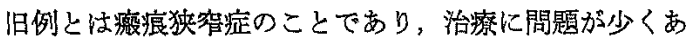
りません．その病態は，1）声門横隔膜形成，2）両側 反回神経麻疩，3）声門下痗痕狭窄，4）気管内肉芽性 狭寯，5）気管食道溇などですが，治療にあたっては狭 窄の状態を明確に知り，適切な治療方針をたてることが 大切です

治療法注 open method と closed method に大別され ます, open method といらのは，新しく低位に気管切開 を行った後，狭窄部を広く開放し，凘痕組織を切除した

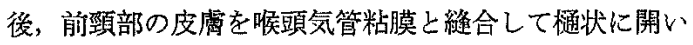
た気道を形成する，再狭窄が起らないことを見極めた後 二次的に開鎖する. closed method とい5のは，同様に 狭窄部を開き，㾿痕組織を切除した後、シリコンゴムの ブロックまたはシリコンチューブを成型して気道内に搨 入し，ナイロン系を貫通させて形部に固定し，喉頭気管 は一次的に閉鎖する. 3 ないし 6 力月後に core mold は 除去する。こういらことであります。，それでは演者の御 経験をきくこととしましょう。

武本：㬋頭・頸部気管外傷の自験例は20例で, その原 因は交通外傷 4 例, 刺傷 1 例，緊急気管切開 2 例, 化学 腐強剂による火傷 1 例，放射線障害による㑨頭敕骨の壤 死 1 例, 両側声帯麻源により呼吸困難を招来した疾患と して甲状腺手術 2 例, 食道喱境 1 例, 不明 3 例であ。 た.この20例のらち菼通外傷による1例と緊急気管切開 2 例は新鮮例で，更に外倁に関保のない声帯麻㾝 4 例を 除く残り13例が外傷性の慢性喉頭気管狭窄症例である. この慢性の狭窄に対しての気道再建法江全例, open method で行った。 その方法は, 1. 壤死㳄骨除去, 2 . 挅形成, 3. 声門前方開大の3つの手術法を障害部位に 応じて組合せて気道を再建する。

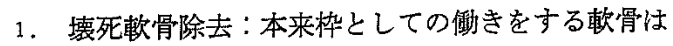
できるだけ除去しない方がよいが，乙が感染した軟骨 が壊死におちいったり，軟骨周囲に膿湟を形成すると㬋 頭または気管内粘膜は強度に腫脹し，同時に皮虞にも著 明な炎症像がみられる，よって腫脹を消頌させるために は壊死におういった軟骨を徹底的に除云することが必要 である。一方，愿染した軟骨を放置すると，軟骨は吸収

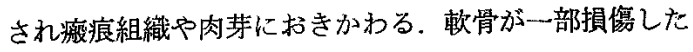
場合は，当該部位に肉芽が登生したり，またはその周四 の結合織が増生して管腔に狭窄をきたす一方軟骨が吸 収されてほとんど撚痕組織におきかわった場合, 堅い枠 としての僛きを失ない蔽痕組織の収縮につれて軟化した 管壁もとを管腔の中心に向ってひきよ吼，同心円状 
の狭窄をきたす。このような場合に行ら処置として枠の 形成がある。

2. 杵形成：枠としての軟骨が大部分残せる場合は狭 窄を起こしている痺㾉組織または肉芽を除去して大きく 開放し，不足した側壁の粘膜はあらかじめゆとりがとれ るよ5に切開した皮覤を管腔内にずらして補充し開放創 とする．時間の経過をともに瘦孔周囲の皮下組織に曒痕 化が進み，この疲痕組織が支持組織として堅い枠の役割 をする。一方ほとんどの軟骨が癜痕組織におきかわっ て，同心円状の狭窄を起している場合は，管腔の粘膜が 保存できれば粘膜下に狭窄を起している瘦痕組織を削除 して管腔を作る。一方削除しても，なお残存している管 腔周囲の瘷痕組織は顿骨様に硬いため，枠としてそのま ま使用することができる，但し，管腔の粘膜が使用でき ないか, 不足している場合は舆腔, 口腔粘膜を移植して 補充する必要がある。このようにして作成した開放性の 管腔にスポンジ様のプロテーゼを入れるが，これは無理 に内腔を拡大するのではなくて，粘膜の圧抵と内腔を適 当な大きさに保持するために約 3 週間挿入する.プロテ 一ゼを除去後，管腔が充分保持されておれば約 1 週間で 外瘦を閉鎖する，大きな瘦孔の時は有茎皮弁を用いて閉 鎖する.

3. 声門前方開大：頸部外傷などにより両側反回神経 麻㾇をきたした場合にわれわれは声門を前方で開大して 気道を再建する方法を考案した。

1) 甲状軟骨方健在の場合は甲状軟骨正中部を縦に 幅 10〜15mm にわたって下粶にわたって下縁より上 $1 / \mathrm{s}$ の高さまで骨スタンツェを用いて取り除き，声帯前連合 部を外部より縦に切り開き，左右の皮膚および甲状軟骨 膜に前連合部粘膜を縫合し開放創とする．約 2 週間スポ ンジを前連合部に插入して皮膚粘膜を圧抵する.

2）甲状軟骨が欠損している場合はまず喉頭の枠形 成を行い, 術後 2 ～ 3 力月間側壁が瘚痕化するのをまっ て, 左右前連合部を左右に㢲引して声門を前方で開大す る.

1)，2）とも声門裂が $4 \mathrm{~mm}$ 以上開くように前方を開大 することが必要である。なお，瘦孔閉鎖は 2 次的に瘦孔 周囲の皮虐を翻転して行う。

以上の上らな3つの手術法を組み合せて慢性の狭窄症 例を治瘾せしめることができたが，その結果次のような 知見を得た。 1) 輸状軟骨, 第1気管に気管切開を行っ た場合は㳄骨端が露出しないように皮虔で覆らと肉芽の 発生などを防ぐことができる，2）喉頭損傷または喉頭
形成後 4 力月間任観察を要する．3）手術操作中できる だけ管腔内粘膜は温存する.4）恢頭软骨の壊死山長期 間の治療を要する. 自験例で最長期閒は22カ月であっ

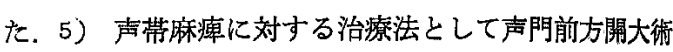
は簡単である.

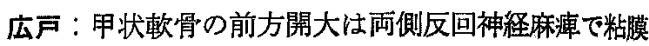
は正常の場合だけですね. 前方開大術を行らと, 甲状㜞 骨の外側部に内方転位するた利梨状陷凹を狭め，術後佂 雀下障害をきたすことはありませんか。

武本：粘膜は正常の場合です. 甲状軟骨の正中前面を 綎に切除致しますから，梨状陌凹を狭めることはありま せん.

黒住：甲状腺手術および気管内㨂管後の反回神経麻哽 症例を除外した自験例の手術療法について述べる。

損傷部位，損傷の程度は症例によって異るので，欢の ような諸方法を症例に念じて適宜選択して行った。

1. 軟骨欠損がないか，あるいは少ない症例

a.内腔病変の軽度のもの。

骨折軟骨の整復固定を行った ( 2 例).

b.内腔病変がかなりあるもの.

瘦痕組織を粘膜下に切除して内腔を広くし，温存した 粘膜は甲状軟骨, 輸状軟骨に縫 合し, 内腔のタンポン （適当な硬さに巻いたシリコンスポンジをゴム膜で包ん だもの)で圧抵 ( 3 例)，内腔粘膜が 使用できない場合 注遊離植皮 ( 3 例).

2. 軟骨久欠損抽よび内腔病変がかなりあるもの.

a，硬化㵝痕を支持枠として役立てる（2 例）.

b . (自家)甲状軟骨移動 (遊離移植) 飞上る枠形成 (2例).

c 肋軟骨移植による枠形成.

i）橋渡し軟骨に陥凹した気管（軟骨欠損）前壁 を钩り上げ，縫合 ( 1 例).

ii）移植軟骨安気管瘦孔に，つっかい䊂状に入 れ，気管内腔の左右経の桩大をはかる ( 1 例).

iii) 移植軟骨に上る喉頭の前後経の拡大 ( 1 例).

d. 腸骨移植による枠形成 ( 1 例).

e. 気管食道瘦閉鎖（討論の項参照）.

以上のような方法で気道再建という目的は概极達成し たが， dの症例では充分でなく，気管孔の開存を必要と したので，追加再建を予定していたところ，患者が自殺 してしまった。また，喉頭粉砕骨折の1例では，骨折軟 骨を整復した後， 1，b，2，b，の方法を行い，内䐩 に mold を入れ, 気道を再建し得たが，諆钼が著しく， 
音声も失声に近い状態で， 1 年後に喉摘を余儀なくされ た. したがってこの症例では喉頭の 3 つの機能の内の 1 つを再建し得たが，他の 2 つには失敗したために，喉摘 を行った訳である.

昨頭気管外甥の治療において優先される心゙きことは， 気道再建であるが，今後は術後の音声の改善に努力しな けれぱならないと考えており，また，上述の症例の如

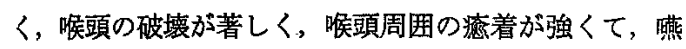

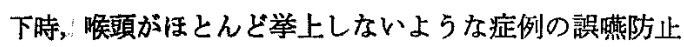
も1つの課題である.

小宮山：最後の症例に対しては，Core mold を挿入し 一次的に術創の閉鎖をはかったらいかがでしょらかか.

黒住：それる多分いい方法だろらと思いますが，私は Core mold に弱いので，ああいら方法によりました．

武本：移植した軟骨が；軟化してしまった症例がある が，そのよらな場合の処理について.

黒住：私はそういう経験を持ちません，軟骨は骨より 選かに安定したもので，余り心配していません．ただ洀 痕組織の中に移植する場合は感染予防に十分留意する必 要があると思います。

小宮山：私どもが経験した痏痕性喉頭気管狭窄症は 8 例である.これらの症例に対し以下のような方針で治療 を行ない，好結果を得ているので報告する。

\section{治療方法}

(1) 喉頭気管の撚痕狭窄の治療にあたっては，喉頭気 管のX線造影を行ない，狭窄部位を立体的に把握したの ち全麻下にマイクロラリンゴスコピーでの観察を行な う.これは喉頭造影写真の所見と比較し，視診だけでな く消息子を使用して触診を行い㾗痕の硬さ, 内腔の状態 方向等を確認するためである。

(2) 痛痕狭窄の状態を充分把握したのち, 外切開（喉 頭截開術・喉頭気管截開術) を加え, 甲状軟骨・輸状軟 骨・気管を露出し，同部の骨折の整復をはかる，また受 賃部の瘵痕・肉芽組織を充分に除去する。

(3) Core mold を作成し，狭窄を呈していた堠頭ある 以は気管内腔に㨉入する. Core mold には, ファイコ ンブロックあるいはシリコンチューブ等を用い，手術時 に内腔に合せて作成する。

(4) Core mold は, 太めのナイロン糸で側䫫部にて固 定する.

(5) Core mold 挿入後 $1 \sim 2$ 週間すると周囲の炎症も 消退し，患者の苦痛は軽減する，また患者は 1 时退院し 日常生活を送ることができるよらになる。
(6) 㨂入された Core mold は $3 \sim 6$ カ月後, 内視鏡 下に除去するが，この時点では肉茅の処置を行わないの が原則である。

(7) Core mold 除去後約 1 力月間は, 浮腫あるいは軟 性肉芽による再狭窄の状熊を呈することがあるが，これ はやがて消失する場合が多いので，この時点での再手術 は極力さけるべきである.

(8) Core mold を除去した症例は，1 $\sim 2$ 力月経過観 察を行い，再㹨绳のみられない場合には，気管孔閉鎖術 を行ら.

治療結果

呼吸機能：この治療法の主目的は気道の再建にある が, 全症例において気管切開孔を閉鎖することができ， ほぼ满足すべき結果を得た。呼吸機能検查を行うことの できた 6 症例の結果を表に示す，気道狭窟を客観的に測 定する方法に関しては，種々の方法が提唱されている が、、ずれも多くの問題点を含んでいる，私どもは 1 秒 率と気道抵抗值を測定し, 正常值との比較を行った。 1 秒率は $70 \%$ 以上を正常範囲とし, 気道抵抗值は，5.0以 上の数值を異常とした.

発声機能：著者らの治療例はすべて中等度以上の嗄声

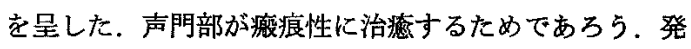
声機能を客観的に知る最も簡単な方法は, 肺活量測定と 発声持続時閒測定である. 発声持続時閒值が 10 秒以上の 場合は，大体会話には不自由を訴えない(表).

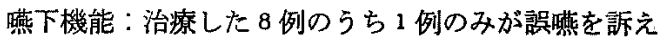
た.この症例に対しては, Core mold 㨂入時に Cricopharyngomyotomy を行い治療させ得た.

\begin{tabular}{rl|l|l|r|rc}
\hline 表 \\
\hline 1
\end{tabular}

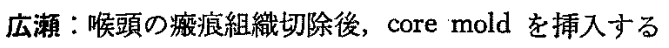
時, 何故 core mold 亿遊離皮弁を巻きつけて植皮しな かったのですか.

小宮山：私の使用した core mold はファイコンブロ ックあるいはシリコンゴムで，硬いので，皮弁を巻きつ 
けても，術後の浮腫出血などで皮弁が圧迫壤死に陥ると 䠸えたからです。

広瀬：われわれの臨床で，過去20年間に取 极った堠 頭，気管損傷症例は14例と少なく，そのほとんどが陳旧 例である。

治療として，例外はあるが，前半期ではT型カニュー レの如き特殊カニューレや、コアーモールドによる狭窄 部の桩大など保存的方法が多く行われ，治湓に長期間を 要し，また結果む不確実な感があった，後半期では積極

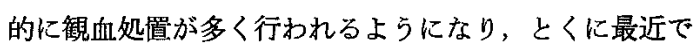
は, 喉頭, 気管の再建・形成術を行っているので, 本日 はその工夫の要点を申し上げる。

いらまでもなく，喉頭・気管は気道を確保できるしっ かりした枠組の再建が必要であり，また内腔では狭寉部 瘵痕を除いた後，粘膜欠損部に対して粘膜加皮虚による 完全な被覆を行って, 激㾗による再狭窄の発生を予防す る必要があり，でき得ればこの二つの条件を同時に満し て，一期的に治瘾せしめ，治療期間を短縮させたい．

以下われわれの方法を症例をあげて説明する。

症例 $1 ： 17$ 才高校生, バイクで疾走中, トラックの荷 台に追突して前頸部を損傷し, 呼吸困難強く, 緊急気管 切開を受けて一命を取りとめ, 受傷後24日目に当科を訪 れた。局所は輸状軟骨を中心に挫滅創があり，レ線では 声門下部に高度の狭窄が認められる、まず気管切開を下 位に行い，創を開放すると，損傷は輪状軟骨，第 1 気管 輪に認められた. 肉芽を十分除却した後, コアー・モー ルドとして手術用ゴム手袋の指中にシリコンスポンジを 固く巻いてつめたものを挿入すると，この部の前側壁に 大きな粘膜欠損部ができる.これに対して縱長の颈部有 茎皮弁で，皮膚面が内腔欠損部を補埃するよう反䎐挿入 するいわゆる island pedicle flap を用いて補った. 輪

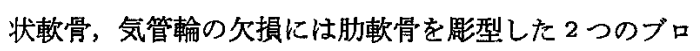
ックを当てがい枠を形成，縫合固定した．皮膚の欠損部 は大きな回転皮弁で被ったところ，傷は一次治灙し，24 日目にモールドを抜去した、レ線でも気道は十分に確保 され，現在バスケットボールもしている由である．

症例 $2 ： 20$ 才男子, バイクの事故で前䁰部を強打し， 呼吸困難高度で気管切開を受け，その後套管拔去困難と なり 2 年 8 カ月を経て送られてきた、レ線で声門部を中

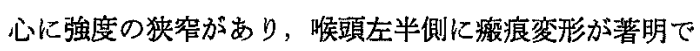
あった，手術はまず気切を下方に移し，皮鬳切開はConley の横皮弁を用意したデザインで行った．甲状敕骨は 正中で離断され，左半分は挫滅，欠損があり，気切は輸
状軟骨になされていた．声門上の変形に対しては laryn. go-micro-surgery の手技を併用して瘵痕を除却した，モ ールドを捅入後, Conley の cervical flap を反転掅入し て，内腔欠損部を補增し，枠として，本例は甲状軟骨の 破砕が著しかったので，腸骨片で，甲状軟骨の補強と， 輪状軟骨欠損部を補填した，左梨子状窩に高度の変形を 残したが，気道は十分に確保され，音声も嗄声はある。 が，現在自衛隊に勤務している。

症例 3：65才男子，農業，破傷風䍜患時呼吸困難のた め緊急気切を受け, 以後套管抜去困難症となり1年半を 経て来院した．本例る輪状軟骨が開かれており，この場 合は甲状軟骨の左側下端を遊離で輪状㳄骨不足部に㨉 入, 固定, 縫合した. 完成した気道はやや狭い憾みがあ るが，日常生活に支障なく過している。本例惊頸部皮弁 を用いず，附近の粘膜の引き奇せで内腔を被ったこと， 軟骨片がやや小さかったことが，気道がやや㹨险化した 原因と考えている。

以上申し上げた一期的再建法は, 当初壊死の発生を危 惧したが，頸部皮弁については，喉頭半切の Conley 法 などの経験から，この優秀性を承知しており，また移植 材料としての軟骨の安定性についても十分経験していた ので，あえて試みた次第である．皮弁の処理など十分注 意潹く行えば，短期間に再建可能で喉頭, 気管の再建の 一方法になり得るものと考える.

小宮山：治滰完了までにどの位の期間を要しました 加.

広瀬：1〜2 カ月です.

黒住 : pedicle island flap を使用した場合, 後に毛が 延びて困ることはありませんか.

広瀬：われわれの症例では毛がのびたものはないか， 術前に Alap のデザインに注意を要します，幸に前项部 はひげが少いが，濃いものは適応ではありません，

值藤：われわれの取扱った症例は69例（阪大43例，熊 大26例，1965〜1975) である.

1）受傷原因

交通外傷, 労働災害, 㔖発事故, 刑事事件, 自殺末遂 および医原性などである，交通外傷のうち最も多いのは 単車事故であり，ついで車より振り落された事故が多 い医原性外甥は最近増加傾向にあり，多くの問題を含 んでいる。

2) 病態診断

頭部外傷を合併した例では，まず意識レベル，aphasia, hemiplegia さらに IQ レベルを知る必要がある。こ 
のよらな合併症があるとリハビリテーションを行いなが ら治療を進めるべきである。

ついで高位気管切開が行われていないかをみて低位に やり直すべきである，その後にあらゆる検查法（レ線，

断層，造影レ線，内視鏡）を用いて狭窄部位，その程 度，その形を診断し，治療方針を立てる．決してあせっ て柱ならない，長期展望の下に計画をたてる。

\section{3）除旧性外傷の病態}

声門㿂詬狭窄 (diaphragma)，声門下腔㴬痕狭窄，肉 芽形成，気管痗疫狭窄，肉芽形成，下咽頭激痕狭窄，晚 頭・下咽頭 - 食道瘦孔，喉頭軟骨骨折 - 軟骨膜炎，反回 神経麻㾝 (両側外転), 後筋麻痺 (両側) などの病態が 䔘察され，これらが複雑に合併していることもある，最 も多いのは声門下腔癞痕狭窄であった。

4) 治源法

病像が把握され，低位気管切開を行った後に次の順序 で治療を行う. 著者の方法は原則として open method である.ゆっくり時間をかけて内腔形成を主眼とし 2 次 的に形成する方法である.

狭害部位を広く前方より開放し，病態を確認する。肉 芽・カリエスを取除き, 癞痕組織を切除する。食道璂が あれば合成縫合采を用い2 層に綪合する。内腔が広くな れば，その上頸部皮膚を用い island pedicle flap とし て内腔に移植固定する。この方法は失敗が少ない. core mold (シリコンチューブなど) を挿入し内腔を碓保す る. この 2 次的開放創は皮膚の定着を持って（普通 $1 \sim$ 2 力月), core mold を技去し前顽部皮膚にて成形縫合 する．その後はしばらく気管開空の安経過をみて， 充分に安全を確めてから閉鎖している. その後 1 年間気 道確保の状況，再発の有無みる必要があり，aphasia， hemiplegia のリハビリテーションを同時に行う.

5）特殊例について

chemical trauma (ソーダ服用自殺) の場合の狭窄は 最も成形がむつかしい，胃管，腸管の举上と喉頭（Marginal stenosis), 下咽頭の成形を行うのであるが，縫合 部の再狭寉が起こり易く，治痽までに相当の日数を要す る. 治㙩中に再び自殺（今度は飛び招り）をはかること がある.

6）医原性外稘について

最近問題となっているのは医療による陳旧性外傷であ り，子供，女性に特に多い。

気管挿管麻醉後の声曼肉芽腫, 反回神経麻疩, 後筋麻 㾝はその多くは治療は简単であるが，長期気管插管麻
酔，人工呼吸後に問題が多い，声門，声門下腔，気管狭 豈がみられる。したがって子供に怯48時間以上の㨂管は 禁忌と考えた方がよい.

また高位気管切開後の声門下腔狭窄も多いので啓蒙が 必要である。

最近では laryngomicrosurgery 後の声帯の diaphragma を経験するようになった。両側声帯前方を同時に手 術することは避けるべきである。

挿管後の気管狭窄は輪状軟骨と第 1 気管輪との間が好 発部位であるが，最近では気管切開口と気管分岐部との 間の狹㑺例がみられるようになった。このような例には 気管切開口より比較的長いシリコンチューブを㨂入する 方法 (これを semi-open method と呼ぶ) にて治療して 招り， $1 \sim 2$ 力月後拔管して治漟している.

結論として，喉頭骨格が最む高度に障害された例で も，最終目標として gutter-like formation 形成が果さ れば音声は確保できる。

広戸：声門横隔膜症に対しては，今や Mc Naught $の$ 術式よりは Alonse の術式の方が良いと思われる. laryngomicrosurgery で膜を切離し，Keel を 3 力月間留置 することによって完全に治瘾し，音声も無声状態からほ とんど正常音声に回復した例を経鈳している。

小児の経鼻挿管に基の゙く声門下腔の狭窄に対しては, 輸状軟骨を正中で切断し，痗痕組織を切除した後，内腔 よりやや大い目のシリコンチューブに遊離皮弃を巻きつ けて挿入し，輪状軟骨の哕開部に注甲状䖝骨正中下縁の 軟骨片を輪状甲状膜を茎として回転して移植し，創を一 次的に閉鎖する，術後は㭧者は経喉頭呼吸も発声も可能 である.チューブは40日後拔去する。この術式を 2 例に 施行し，2 例とも成功したから，小児の声閒下狭窄に対 してはこの術式を routine と考えて良いと思う。

さて，気管食道瘦閉鎖の経験をもたれた方はありませ んか.

黒住：84才，男性，肺水嗹のた的，気管内㨂管，気管 切開, 擩管後 13 日頃上り気管食道瘦形成, 肺病変のやや 好転した挿管後 1 年で, 瘦孔閏鎖術を行った。気管壁.

食道壁を別々に縫合し，Fascia leta を用いて強化した。

佐藤：3例経験している。これは生命に直結する最も 重要な外傷であり，その縫合には慎重な配虑がいる，合 成縫合采を用い 2 層に縫合する。

広戸：開放治療で二次的に気管を開しる場合, 軟骨支 持物がなくても，1cm の厚さがあれば軟部組織だけでも 支障はないと思う。 
core mold として Solid なものを使用すると誤蟪は 起らないが発声ができない，tube を用いると発声はで きるが摆嬹が起る場合がある。この使い分けについての 意見は?.

小宮山：原則として，喉頭に対しては Solid な core mold，気管に対しては tube の core mold を使用してい
広戸 : いろいろ貴重な御経験を提示して頂き有難らご ざいました．治療方針そのもの梳不変でありますので, 本日の討議で結論めいたものをだすことは差控えます． 演者はそれぞれ具体的化述べられましたから，それを汲 み取って明日えの糧にして頂ければ幸いです，それでは これで終ります。 る.

\section{[パネルディスカッション II]}

\section{メ}

司会 渡辺 勈 (東医歯大) ・朴沢二郎 (東北大) ・ 北原正章 (京大) 長場雅男（新 大）・時田 喬 (岐卓大) ・鈴木淳一（帝京大） 内 藤 㩦 (阪大)

\section{司会者のまえおき}

歴史的にみると，すでに今世紀の初頭かららニエール 病の外科的治療についての報告があり，はじめは第 8 神 経の切断や，半規管・前庭部の開放などの患側の内耳機 能を㬢牲にするむのばかりであったが，その後，内耳機 能とくに聴覚の保存を祆らった手術法（たとえば内リン パ蕒開放術など）も考案された.

さらに，マイクロサージャリーの技法が普及するにつ れて, 多種多様の耳科的・脳外科的術式とその治療成續 とが報告され，それらの評価をめぐる論議も盛んに行わ れつつあるが，単にそれらの報告や討論記事を読んだだ けでは, その術式の適応・効果・安全性などについての 確かな知識をうることがむつかしく，したがって自分の 担当している症例がその適応となるか否かの判定, 予後 の推測ができかねることが多い

また,わが国机いては戦後メニエール病症例数の激 増をみたとはいえ，欧米諸国と比較すると手術症例の割 合は少ない。この理由として,わが国におけるメニエー ル病と欧米のそれとの間に，何らかの質的・量的な相異 があるのではないか，あるいは診断基準・手術適応・社 会的条件などの違いによるのではないか，などの論議も なされている。

さて，司会者は，従来報告された手術方法を試みに下 記の4群に分類してみた.

I 群：内耳沙るいは聴神経に直接の操作を加えること なく，遠隔または隣接部位よりの間接的効果をねらうも
の．たとえば扁桃炎などの病巣除去手術, 星状神経節摘 出術, 鼓荣切断および鼓室神経叢切除術など.

II 群：「内リンパ水腫」の存在を臨床的に推定しこ れに対する各種の減荷・ドレナージなどの操作を行うも

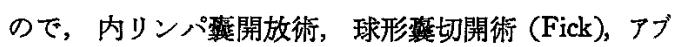
ミ骨底板鋲打ち手術 (Tack Operation一Cody)などがこ れに属するむのと考えられる。

III群：患側の前庭あるい忙半規管の感営装置の破㵵， あるいは聴神経前庭枝の切断によってめまい発作の再発 を防止し，中枢性の代償による平衡機能の回復を期待す るとともに，聴覚の保存ないしは改善をはかららとする もので, 前庭神経の内耳道内切断および前庭神経節の切 除，半規管壁からの超音波照射などがある（但し超音皮 照射は単なる破壊のみでなく，内耳病変の改善を机らら 場合も最近では考えられている（後出の時田の論文参 照).

IV群：患側の前庭機能のみでなく，聴覚も犠牲にする が，めまいの発作をもっとも確実に消失せしめようとす るむので, 膜迷路摘出術, 経迷路前庭切断術などがこれ に属する.この際, 患側の難聴は高度で回復の可能性の ないことが条件である。

これらの手術法は，メニエール病の真の原因肪不明か 現在, いずれも一種の対症療法にすぎないとの可能性法 つねに念頭におかなければならない。

結局，われわれは，臨床的に非観血的治療の隄界をる とめ，外科的治療がその限界を超えて有效性をむつとの 